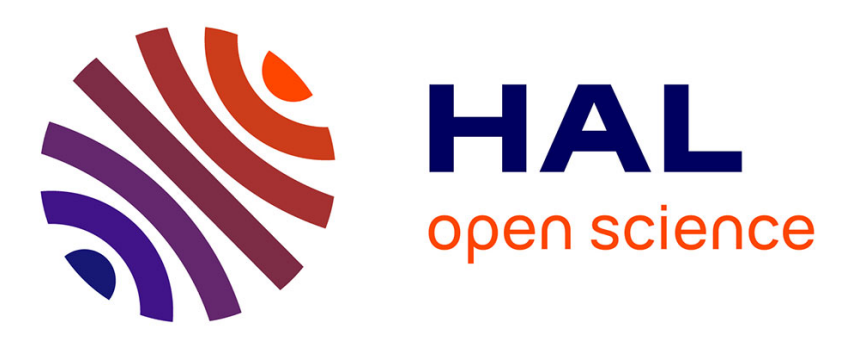

\title{
Assembling CuIILnIIIOsIII heterotrimetallic octanuclear complexes and 1D coordination polymers from the same molecular modules
}

\author{
Andreea Dogaru, Jun-Liang Liu, Catalin Maxim, Gabriela Marinescu, \\ Rodolphe Clérac, Marius Andruh
}

\section{To cite this version:}

Andreea Dogaru, Jun-Liang Liu, Catalin Maxim, Gabriela Marinescu, Rodolphe Clérac, et al.. Assembling CuIILnIIIOsIII heterotrimetallic octanuclear complexes and 1D coordination polymers from the same molecular modules. Polyhedron, 2020, 175, pp.114242. 10.1016/j.poly.2019.114242 . hal02409485

\section{HAL Id: hal-02409485 \\ https://hal.science/hal-02409485}

Submitted on 24 Nov 2020

HAL is a multi-disciplinary open access archive for the deposit and dissemination of scientific research documents, whether they are published or not. The documents may come from teaching and research institutions in France or abroad, or from public or private research centers.
L'archive ouverte pluridisciplinaire HAL, est destinée au dépôt et à la diffusion de documents scientifiques de niveau recherche, publiés ou non, émanant des établissements d'enseignement et de recherche français ou étrangers, des laboratoires publics ou privés. 


\section{Assembling $\left\{\mathrm{Cu}^{\mathrm{II}} \mathrm{Ln}^{\mathrm{III}} \mathrm{Os}^{\mathrm{III}}\right\}$ heterotrimetallic octanuclear complexes and 1D coordination polymers from the same molecular modules}

Andreea Dogaru ${ }^{\mathrm{a}}$, Jun-Liang Liu ${ }^{\mathrm{b}}$, Catalin Maxim ${ }^{\mathrm{c}}$, Gabriela Marinescu ${ }^{\mathrm{d}}$, Rodolphe Clérac ${ }^{\mathrm{b}, *}$, Marius Andruh ${ }^{\mathrm{C}, *}$

a “C. D. Nenitzescu” Institute of Organic Chemistry, Romanian Academy, Splaiul Independentei, no. 202B, Bucharest, Romania ${ }^{\mathrm{b}}$ Univ. Bordeaux, CNRS, Centre de Recherche Paul Pascal, UMR 5031, 33600 Pessac, France

${ }^{\mathrm{C}}$ University of Bucharest, Faculty of Chemistry, Inorganic Chemistry Laboratory, Str. Dumbrava Rosie nr. 23, 020464-Bucharest, Romania

d "Ilie Murgulescu" Institute of Physical Chemistry, Romanian Academy, Spl. Independentei no. 202, 060021-Bucharest, Romania 
Four 3d-5d-4f heterotrimetallic complexes have been assembled from $\left\{\mathrm{Cu}_{2}^{\mathrm{II}} \mathrm{Ln}^{\mathrm{III}}\right\}$ building-blocks and the Os(III) metalloligand, $\left[\mathrm{Os}(\mathrm{CN})_{6}\right]^{3-}$. Two of the coordination assemblies are octanuclear metallocycles, [ $[(\mathrm{Cu}$ (valdmpn) $\left.\left.)_{4} \mathrm{Ln}_{2}\left(\mathrm{H}_{2} \mathrm{O}\right)_{2}\right\}\left\{\mathrm{Os}(\mathrm{CN})_{6}\right\}_{2}\right] \cdot 3 \mathrm{CH}_{3} \mathrm{OH} \cdot 4 \mathrm{H}_{2} \mathrm{O} \cdot \mathrm{CH}_{3} \mathrm{CN}\left(\mathrm{Ln}=\mathrm{Gd} \mathrm{1}\right.$, Tb 2), while the two others, ${ }_{\infty}^{1}[\{(\mathrm{Cu}$ (valdmpn) $\left.\left.)_{2} \mathrm{Ln}\left(\mathrm{CH}_{3} \mathrm{OH}\right)\right\}\left\{\mathrm{Os}(\mathrm{CN})_{6}\right\}\right] \cdot 5 \mathrm{CH}_{3} \mathrm{OH} \cdot \mathrm{H}_{2} \mathrm{O}(\mathrm{Ln}=\mathrm{Gd} \mathrm{3}$, Tb 4), are one-dimensional (1D) coordination polymers $\left(\mathrm{H}_{2}\right.$ valdmpn is the Schiff base resulted from the condensation of 0 -vanillin with 2,2-dimethylpropylenediamine). The final type of assembly (molecular OD versus 1D) is clearly influenced by the nature of the employed solvents. The magnetic properties of the four compounds have been investigated revealing the expected ferromagnetic $\mathrm{Cu}^{\mathrm{II}}-\mathrm{Ln}^{\mathrm{III}}$ magnetic interactions in the $\left\{(\mathrm{Cu}(\mathrm{valdmpn}))_{2} \mathrm{Ln}\left(\mathrm{CH}_{3} \mathrm{OH}\right)\right\}$ moiety and weak $\mathrm{Cu}^{\mathrm{II}}-\mathrm{NC}-\mathrm{O} \mathrm{s}^{\mathrm{III}}$ antiferromagnetic coupling $\left(\mathrm{Jcu}-\mathrm{Os} / \mathrm{k}_{\mathrm{B}} \approx-0.6 \mathrm{~K}\right)$ in the gadolinium based complexes 1 and 3. 


\section{Introduction}

The combination of different paramagnetic metal ions within the same molecular entity is of high interest in molecular magnetism, as the magnetic interaction between these spin carriers can be easily controlled to obtain materials with desired properties (3D molecule-based magnets, Single-Molecule Magnets and Single-Chain Magnets) [1]. A vast majority of the heterometallic complexes contain only two metal ions in various stoichiometry. In contrast, heterotrimetallic complexes are more difficult to obtain and represent a real challenge from the synthetic point of view. The main problem faced by chemists is to avoid the scrambling of the metal ions with the different ligands. In a rational way, heterotrimetallic complexes can be assembled following different strategies: ( $i$ ) using the selective coordination of the three metal ions by single ligand with three different coordination sites [2]; (ii) using metalloligands like an anionic heterobinuclear complex with potentially bridging groups able to coordinate a third metal ion [3], or (iii) an anionic mononuclear metalloligand able to coordinate one or two metal ions from a heterometallic cationic complex [4]. The preformed heterobimetallic modules, binuclear or with higher nuclearities, are usually assembled using compartmental ligands with different sets of donor atoms. This last strategy can be adapted in order to obtain either heterometallic complexes or coordination polymers. Indeed, several heterotrimetallic complexes showing exciting properties, were obtained by one-pot reactions [5].

Our synthetic approach toward heterotrimetallic complexes consists of self-assembly processes involving cationic oligonuclear modules, $\left\{\mathrm{M}^{\mathrm{II}} \mathrm{Ln}^{\mathrm{III}}\right\}$ and $\left\{\mathrm{M}^{\mathrm{II}} \mathrm{Ln}^{\mathrm{III}} \mathrm{M}^{\mathrm{II}}\right\}$, and various homo- and heteroleptic cyanido metalloligands like $\left[\mathrm{M}(\mathrm{CN})_{6}\right]^{3-}$, $[\mathrm{M}(\mathrm{bipy})$ $\left.(\mathrm{CN})_{4}\right]^{-},\left[\mathrm{M}(\mathrm{phen})(\mathrm{CN})_{4}\right]^{-}(\mathrm{M}=\mathrm{Fe}, \mathrm{Cr}),\left[\mathrm{M}(\mathrm{CN})_{8}\right]^{3-}(\mathrm{M}=\mathrm{Mo}, \mathrm{W})$ or $\left[\mathrm{W}(\text { bipy })(\mathrm{CN})_{6}\right]^{-}[6]$. The $3 \mathrm{~d}-4 \mathrm{f}$ modules are formed systematically using compartmental Schiff-base ligands derived from $o$-vanillin $\left(\mathrm{H}_{2}\right.$ valXn). The reaction between $[\mathrm{M}(\mathrm{valXn})]$ and lanthanide salts affords binuclear complexes: $[\mathrm{M}(\mathrm{valXn}) \mathrm{Ln}]^{3+}$. During the selfassembly processes, a second $[\mathrm{M}(\mathrm{valXn})]$ unit can coordinate to the lanthanide ion, resulting in trinuclear $\left[\mathrm{M}^{\mathrm{II}} \mathrm{Ln}^{\mathrm{III}} \mathrm{M}^{\mathrm{II}}\right]$ species. This process is favored by poorly coordinating anions or by the preestablished molar ratio $\left[\mathrm{M}^{\mathrm{II}}(\right.$ valXn $\left.)\right]: \operatorname{Ln}^{\mathrm{III}}=2: 1$. Both binuclear and trinuclear species can act as molecular modules in constructing high nuclearity complexes and coordination polymers. Following this route, we reported on several families of $\left\{\mathrm{M}^{\mathrm{II}} \mathrm{Ln}^{\mathrm{III}} \mathrm{Fe}^{\mathrm{III}}\left(\mathrm{Cr}^{\mathrm{III}}\right)\right\}$ 
and $\left\{\mathrm{M}^{\mathrm{II}} \mathrm{Ln}^{\mathrm{III}} \mathrm{Mo}^{\mathrm{V}}\left(\mathrm{W}^{\mathrm{V}}\right)\right\}$ complexes $(\mathrm{M}=\mathrm{Cu}, \mathrm{Ni})[6]$. The nature of the resulting systems is strongly influenced by the val $\mathrm{Xn}^{2-}$ ligands, which can be finely modified by simply changing the diamine in the condensation reaction with $o$-vanillin, leading to very different heterotrimetallic complexes [6a,c]. In this work, we show that the nature of the resulting complexes (oligonuclear species vs. coordination polymers) is also strongly influenced by the solvents chosen for the synthesis.

In comparison with $3 \mathrm{~d}$-based $\left[\mathrm{M}(\mathrm{CN})_{6}\right]^{3-}$ modules, $\left[\mathrm{Ru}(\mathrm{CN})_{6}\right]^{3-}$ and $\left[\mathrm{Os}(\mathrm{CN})_{6}\right]^{3-}$ have been much less employed in designing heterometallic systems [7]. Herein, we report on the first $\left\{\mathrm{Cu}^{\mathrm{II}} \mathrm{Ln}^{\mathrm{III}}\right.$ $\left.\mathrm{Os}^{\mathrm{III}}\right\}$ heterotrimetallic species, which are constructed using [Os $\left.(\mathrm{CN})_{6}\right]^{3-}$ as a metalloligand. Four new heterotrimetallic complexes have been obtained starting from [Cu(valdmpn)], $\mathrm{Ln}\left(\mathrm{NO}_{3}\right)_{3} \cdot 5 \mathrm{H}_{2} \mathrm{O}$ and $\left(\mathrm{PPh}_{4}\right)_{3}\left[\mathrm{Os}(\mathrm{CN})_{6}\right]$ precursors $\left(\mathrm{H}_{2}\right.$ valdmpn results from $o$-vanillin and 2,2-dimethyl-propylenediamine - Scheme 1). Their crystals structures and magnetic properties are discussed.

\section{Experimental}

\subsection{Materials and methods}

Commercially available reagents were used without further purification. The two precursors, $\left[\mathrm{Cu}\right.$ (valdmpn)] and $\left(\mathrm{PPh}_{4}\right)_{3}[\mathrm{Os}$ $\left.(\mathrm{CN})_{6}\right]$, were obtained following the synthetic procedures reported in the literature $[8,9], \mathrm{H}_{2}$ valdmpn is the Schiff base resulting from the condensation of $o$-vanillin with 2,2-dimethyl-propylenediamine. The four complexes have been synthesized using a similar method: the trinuclear species are generated in situ by adding the hydrated lanthanide nitrate into a methanolic solution containing $[\mathrm{Cu}(\mathrm{valdmpn})]$. The subsequent addition of either acetonitrile $(\mathbf{1}$ and $\mathbf{2}$ ) or methanolic (3 and $\mathbf{4})$ solutions of the $\left[\mathrm{Os}(\mathrm{CN})_{6}\right]^{3-}$ metalloligand affords the four complexes described below.

\subsection{Physical measurements}

IR spectra ( $\mathrm{KBr}$ pellets) were recorded on a Tensor $37 \mathrm{spec}-$ trophotometer in the $4000-400 \mathrm{~cm}^{-1}$ region. The magnetic measurements were carried out with the use of Quantum Design MPMS-XL SQUID magnetometer. This instrument works between 1.8 and $400 \mathrm{~K}$ with applied dc fields ranging from -7 to $7 \mathrm{~T}$. Measurements were performed on a polycrystalline samples of $\mathbf{1}, \mathbf{2}, \mathbf{3}$ and $4(9.57,2.34,8.24$ and $10.54 \mathrm{mg})$ covered their frozen mother liquor within a sealed straw to prevent desolvation of the solid. Only experiments done with compounds maintained in frozen mother liquor led to reproducible dc and ac magnetic data. No evaporation of the mother liquor was observed during these measurements. The mass of the sample was determined after the measurements and subsequent mother liquor evaporation. Prior to the experiments, the field-dependent magnetization was measured at $100 \mathrm{~K}$ in order to confirm the absence of any bulk ferromagnetic impurities. Ac susceptibility measurements were performed with an oscillating field of 3 Oe with ac frequencies from 1 to $1500 \mathrm{~Hz}$; but no out-of-phase ac signal could be detected above $1.8 \mathrm{~K}$ in the available experimental temperature, ac frequency and dc field windows. The magnetic data were corrected for the sample holder, mother liquor and the intrinsic diamagnetic contributions.

\subsection{Syntheses}

\subsubsection{Synthesis of complexes $\mathbf{1}$ and $\mathbf{2}$}

$\left[\left\{(\mathrm{Cu}(\text { valdmpn }))_{4} \mathrm{Ln}_{2}\left(\mathrm{H}_{2} \mathrm{O}\right)_{2}\right\}\left\{\mathrm{Os}(\mathrm{CN})_{6}\right\}_{2}\right] \cdot 3 \mathrm{CH}_{3} \mathrm{OH} \cdot 4 \mathrm{H}_{2} \mathrm{O} \cdot \mathrm{CH}_{3} \mathrm{CN}$ $(\mathrm{Ln}=\mathrm{Gd} \mathrm{1}, \mathrm{Tb} 2)$ to a methanolic solution $(10 \mathrm{~mL})$ containing $[\mathrm{Cu}(-$ valdmpn)] (10 mg, $0.02 \mathrm{mmol})$ and $\mathrm{Gd}\left(\mathrm{NO}_{3}\right)_{3} \cdot 5 \mathrm{H}_{2} \mathrm{O}(\mathbf{1}) / \mathrm{Tb}\left(\mathrm{NO}_{3}\right)_{3}-$ $.5 \mathrm{H}_{2} \mathrm{O}$ (2) $(5 \mathrm{mg}, 0.01 \mathrm{mmol})$, a solution of $\left(\mathrm{PPh}_{4}\right)_{3}\left[\mathrm{Os}(\mathrm{CN})_{6}\right]$ $(15 \mathrm{mg}, 0.01 \mathrm{mmol})$ in acetonitrile $(10 \mathrm{~mL})$ was added. The resultant green solutions were stirred overnight. After filtration, the filtrates were slowly evaporated at room temperature for five days to afford green crystals, either of $\mathbf{1}$ and $\mathbf{2}$, suitable for X-Ray diffraction. IR data $\left(\mathrm{KBr}, \mathrm{cm}^{-1}\right): 2958 \mathrm{w}, 2087 \mathrm{~m}\left(\bar{v}_{\mathrm{CN}}\right), 2026 \mathrm{~m}\left(\bar{v}_{\mathrm{CN}}\right)$, 1628 s, 1474 s, 1392w, 1289 s, 1229 s, $1171 w, 1067$ m, 971w, 931w, 852w, $741 \mathrm{~m}, 646 \mathrm{w}$ (for 1); 2944w, $2086 \mathrm{~m}\left(\bar{v}_{\mathrm{CN}}\right), 2026 \mathrm{w}$ $\left(\bar{v}_{\mathrm{CN}}\right), 1628 \mathrm{~s}, 1474 \mathrm{~s}, 1392 \mathrm{w}, 1289 \mathrm{~s}, 1229 \mathrm{~s}, 1171 \mathrm{~m}, 1067 \mathrm{~m}$, $971 \mathrm{w}, 931 \mathrm{w}, 852 \mathrm{w}, 738 \mathrm{~m}, 646 \mathrm{w}$ (for 2).

\subsubsection{Synthesis of complexes $\mathbf{3}$ and $\mathbf{4}$}

$1_{\infty}\left[\left\{(\mathrm{Cu}(\text { valdmpn }))_{2} \mathrm{Ln}\left(\mathrm{CH}_{3} \mathrm{OH}\right)\right\}\left\{\mathrm{Os}(\mathrm{CN})_{6}\right\}\right] \cdot 5 \mathrm{CH}_{3} \mathrm{OH} \cdot \mathrm{H}_{2} \mathrm{O}$

( $\mathrm{Ln}=\mathrm{Gd} \mathrm{3,} \mathrm{Tb} \mathrm{4):} \mathrm{to} \mathrm{a} \mathrm{methanolic} \mathrm{solution}(10 \mathrm{~mL})$ containing $[\mathrm{Cu}$ (valdmpn)] (10 mg, $0.02 \mathrm{mmol})$ and $\mathrm{Gd}\left(\mathrm{NO}_{3}\right)_{3} \cdot 5 \mathrm{H}_{2} \mathrm{O}(3) / \mathrm{Tb}\left(\mathrm{NO}_{3}\right)_{3^{-}}$ $.5 \mathrm{H}_{2} \mathrm{O}(4)(5 \mathrm{mg}, 0.01 \mathrm{mmol})$, a solution of $\left(\mathrm{PPh}_{4}\right)_{3}\left[\mathrm{Os}(\mathrm{CN})_{6}\right]$ $(15 \mathrm{mg}, 0.01 \mathrm{mmol})$ in methanol $(10 \mathrm{~mL})$ was added. The resultant green solutions were stirred for one hour. After filtration, the filtrates were slowly evaporated at room temperature for two days to afford green crystals, either of $\mathbf{3}$ and $\mathbf{4}$, suitable for single-crystal X-Ray diffraction. IR $\left(\mathrm{KBr}, \mathrm{cm}^{-1}\right)$ : 2955w $2089 \mathrm{~m}\left(\bar{v}_{\mathrm{CN}}\right), 2029 \mathrm{w}$ $\left(\bar{v}_{\mathrm{CN}}\right), 1627 \mathrm{~s}, 1474 \mathrm{~s}, 1392 \mathrm{w}, 1289 \mathrm{~s}, 1229 \mathrm{~s}, 1165 \mathrm{w}, 1065 \mathrm{~m}$, 970w, 930w, 852w, $740 \mathrm{~m}$ (for 3); 2955w, $2083 \mathrm{~m}\left(\bar{v}_{\mathrm{CN}}\right), 2025 \mathrm{w}$ $\left(\bar{v}_{\mathrm{CN}}\right), 1629 \mathrm{~s}, 1475 \mathrm{~s}, 1392 \mathrm{w}, 1287 \mathrm{~s}, 1229 \mathrm{~s}, 1168 \mathrm{w}, 1063 \mathrm{~m}$, 972w, 931w, 853w, 739 m (for 4).<smiles>COc1cccc(C=NCC(C)(CN)C/N=C/c2cccc(OC)c2O)c1O</smiles> 


\subsection{X-ray data collection and crystal structure refinement}

The single-crystal X-ray diffraction measurements for complexes 1 and $\mathbf{4}$ were performed at $173 \mathrm{~K}$ on a STOE IPDS II diffractometer operating with a $\mathrm{Mo}_{\mathrm{K} \alpha}(\lambda=0.71073 \AA)$ X-ray tube equipped with a graphite monochromator. The structures were solved by direct method (SHELXS-97) and refined by full-matrix least squares techniques based on $F^{2}$. A summary of the crystallographic data and the structure refinement for crystals $\mathbf{1}$ and $\mathbf{4}$ are given in Table 1 . Unit cell parameters for compound 2: $a=13.523, \quad b=13.880, \quad c=17.897 \AA ; \quad \alpha=99.60, \quad \beta=99.24$, $\gamma=100.79^{\circ}, V=3200 \AA^{3}$; Unit cell parameters for compound 3: $a=18.6188, b=25.3620, c=26.6534 \AA \AA \alpha=90, \beta=90.276, \gamma=90^{\circ}$, $V=12585.85 \AA^{3}$.

\section{Results and discussion}

\subsection{Syntheses and general description}

The four compounds, octanuclear complexes [ $\left\{(\mathrm{Cu}(\mathrm{valdmpn}))_{4}\right.$ - $^{-}$ $\left.\left.\mathrm{Ln}_{2}\left(\mathrm{H}_{2} \mathrm{O}\right)_{2}\right\}\left\{\mathrm{Os}(\mathrm{CN})_{6}\right\}_{2}\right] \cdot 3 \mathrm{CH}_{3} \mathrm{OH} \cdot 4 \mathrm{H}_{2} \mathrm{O} \cdot \mathrm{CH}_{3} \mathrm{CN}(\mathrm{Ln}=\mathrm{Gd} \mathrm{1}$, Tb 2) and $1 \mathrm{D}$ coordination polymers, ${ }_{\infty}\left[\left\{(\mathrm{Cu}(\text { valdmpn }))_{2} \mathrm{Ln}\left(\mathrm{CH}_{3} \mathrm{OH}\right)\right\}\{\mathrm{Os}\right.$ $\left.\left.(\mathrm{CN})_{6}\right\}\right] \cdot 5 \mathrm{CH}_{3} \mathrm{OH} \cdot \mathrm{H}_{2} \mathrm{O}(\mathrm{Ln}=\mathrm{Gd} \mathrm{3}, \mathrm{Tb} 4)$ have been obtained from the same modules but using different solvents during the synthesis. Complexes $\mathbf{1}$ and $\mathbf{2}$ are obtained from a methanol:acetonitrile (1:1) solution, while $\mathbf{3}$ and $\mathbf{4}$ are stabilized using only methanol. Compounds $\mathbf{1}$ and $\mathbf{2} / \mathbf{3}$ and $\mathbf{4}$ are isostructural and the crystal structures for $\mathbf{1}$ and $\mathbf{4}$ have been solved and described here in detail, while the unit cell of $\mathbf{2}$ and $\mathbf{3}$ were enough to confirm their respective isomorphism (see details in the experimental part). The IR spectra reveal the formation of the Schiff-base ligand (with bands in the $1600 \mathrm{~cm}^{-1}$ region) and confirm the presence of the cyanido groups with bands in the range $2000-2100 \mathrm{~cm}^{-1}: 2087$ and $2026 \mathrm{~cm}^{-1}$ for 1,2086 and $2026 \mathrm{~cm}^{-1}$ for 2,2089 and $2029 \mathrm{~cm}^{-1}$ for 3, and, respectively 2083 and $2025 \mathrm{~cm}^{-1}$ for 4 .

\subsection{Crystal structure of complex $\mathbf{1}$}

The crystal structure of compound $\mathbf{1}$ consists of a centrosymmetric octanuclear complex, composed of two $\left\{(\mathrm{Cu}(\mathrm{valdmpn}))_{2}-\right.$ $\mathrm{Gd}\}^{3+}$ modules connected by two $\left\{\mathrm{Os}(\mathrm{CN})_{6}\right\}^{3-}$ metalloligands through two cis cyanido groups (Fig. 1). Two crystallographically

Table 1

Crystallographic data, details of data collection and structure refinement parameters for compounds $\mathbf{1}$ and $\mathbf{4}$

\begin{tabular}{|c|c|c|}
\hline & 1 & 4 \\
\hline Empirical formula & $\mathrm{C}_{106} \mathrm{H}_{132} \mathrm{Cu}_{4} \mathrm{~N}_{22} \mathrm{O}_{32} \mathrm{Os}_{2} \mathrm{Gd}_{2}$ & $\mathrm{C}_{54} \mathrm{H}_{74} \mathrm{Cu}_{2} \mathrm{~N}_{10} \mathrm{O}_{15} \mathrm{OsTb}$ \\
\hline$M\left(\mathrm{~g} \mathrm{~mol}^{-1}\right)$ & 3173.37 & 1579.43 \\
\hline Temperature, (K) & $173(2)$ & $173(2)$ \\
\hline Wavelength, (Å) & 0.71073 & 0.71073 \\
\hline Crystal system & Triclinic & Orthorombic \\
\hline Space group & $P-1\left(n^{0} 2\right)$ & $\operatorname{Pbca}\left(\mathrm{n}^{\circ} 61\right)$ \\
\hline$a(\AA)$ & $13.5607(3)$ & $18.5173(6)$ \\
\hline$b(\AA)$ & $13.8309(4)$ & $25.4327(10)$ \\
\hline$c(\AA)$ & $17.7822(5)$ & $26.5352(12)$ \\
\hline$\alpha\left(^{\circ}\right)$ & $98.853(6)$ & 90 \\
\hline$\beta\left(^{\circ}\right)$ & $99.132(7)$ & 90 \\
\hline$\gamma\left({ }^{\circ}\right)$ & $101.026(8)$ & 90 \\
\hline$V\left(\AA^{3}\right)$ & $3173.16(19)$ & 12496.6(9) \\
\hline$Z$ & 1 & 8 \\
\hline$D_{\mathrm{c}}\left(\mathrm{g} \mathrm{cm}^{-3}\right)$ & 1.661 & 1.679 \\
\hline$\mu\left(\mathrm{mm}^{-1}\right)$ & 3.759 & 3.887 \\
\hline$F\left(\begin{array}{lll}0 & 0 & 0\end{array}\right)$ & 1572 & 6296 \\
\hline Goodness-of-fit on $F^{2}$ & 1.064 & 0.797 \\
\hline Final $R_{1}^{\mathrm{a}}, w R_{2}^{b}[I>2 \sigma(I)]$ & $0.0637,0.1858$ & $0.0547,0.1003$ \\
\hline$R_{1}^{\mathrm{a}}, w R_{2}^{b}$ (all data) & $0.0875,0.2002$ & $0.1442,0.1232$ \\
\hline $\begin{array}{l}\text { Largest diff. peak and } \\
\quad \text { hole }\left(e \AA^{-3}\right)\end{array}$ & $2.643,-2.500$ & $1.545,-1.347$ \\
\hline
\end{tabular}

independent [ $\mathrm{Cu}(\mathrm{valdmpn})]$ units are coordinated through their outer $\mathrm{O}_{2} \mathrm{O}_{2}$ cavities to the $\mathrm{Gd}^{\mathrm{III}}$ ion (two oxygen atoms arise from the phenoxido groups and the two others from the methoxy ones) thus forming an almost linear trimetallic moiety $\left[170.37(4)^{\circ}\right]$. The $\mathrm{Gd}(\mathrm{III})$ site is nine-coordinated in a distorted muffin-like geometry $\left(C_{S}\right.$ symmetry estimated through SHAPE 2.1 program, see Fig. S1 and Table S1 in ESI) [10]. Its coordination sphere is constructed by eight oxygen atoms from two [ $\mathrm{Cu}(\mathrm{valdmpn})]$ units, and one aqua ligand. The nine $\mathrm{Gd}-\mathrm{O}$ distances vary between 2.603(9) and 2.331(9) $\AA$. The copper ions display a square pyramidal geometry, with the equatorial plane occupied by the oxygen and nitrogen atoms from the compartmental ligand, while the apical positions are occupied by the nitrogen atoms arising from the cyanido bridges [Cu1 - O6 $=1.944(9), \mathrm{Cu} 1-\mathrm{O} 7=2.004(8), \mathrm{Cu} 1-$ N7 = 1.998(10), Cu1 $-\mathrm{N} 8=1.967(10) ; \mathrm{Cu} 2-\mathrm{O} 1=1.962(8), \mathrm{Cu} 2-$ $\mathrm{O} 005=1.957(9), \mathrm{Cu} 2-\mathrm{N} 9=1.972(11), \mathrm{Cu} 2-\mathrm{N} 10=1.981(10)$, Cu1 $-\mathrm{N} 1=2.228(12)$, and Cu2 $-\mathrm{N} 5=2.313(12) \AA)]$. The values of the trigonality parameter [11] for the five-coordinate copper (II) ions are: $\tau_{\mathrm{Cu} 1}=26.86$ and, respectively, $\tau_{\mathrm{Cu} 2}=19.81 \%$. The intra-module $\mathrm{Cu} \cdots \mathrm{Gd}$ distances are 3.523 and $3.528 \AA$, while the distances between the copper and osmium atoms across the cyanido bridges are: $\mathrm{Cu} 1 \ldots \mathrm{Os} 1^{i}=5.364(19)$ and $\mathrm{Cu} 2 \cdots \mathrm{Os} 1=5.186$ (18) $\AA\left({ }^{i}=2-x, 1-y, 2-z\right)$. The Os-CN-Cu fragments are bent with $\mathrm{CN}-\mathrm{Cu}$ angles being $141.46(11)$ and $163.64(11)^{\circ}$. It is worth noting that an octanuclear complex, $\left[\mathrm{Ni}_{2} \mathrm{Dy}_{4} \mathrm{Fe}_{2}\right]$, with a similar topology was obtained recently by Kou et al. using the more common $\left[\mathrm{Fe}(\mathrm{CN})_{6}\right]^{3-}$ module as a metalloligand [12]. Selected bond distances and angles for compound $\mathbf{1}$ are collected in Table S2.

\subsection{Crystal structure of complex 4}

The crystal structure of $\mathbf{4}$ consists of a one-dimensional coordination polymer made of the same molecular modules as seen for complex 1, with $\left\{(\mathrm{Cu}(\text { valdmpn }))_{2} \mathrm{~Tb}\right\}^{3+}$ nodes bridged by [Os $\left.(\mathrm{CN})_{6}\right]^{3-}$ spacers (Fig. 2). The asymmetric unit and the atom numbering scheme are presented in Fig. S2 in ESI. The metalloligand, $\left[\mathrm{Os}(\mathrm{CN})_{6}\right]^{3-}$, involves again two cis cyanido groups in the coordination to the $\left\{(\mathrm{Cu}(\text { valdmpn }))_{2} \mathrm{~Tb}\right\}^{3+}$ units. The terbium ion is also located into the $\mathrm{O}_{2} \mathrm{O}_{2}$ large and open compartment of the organic ligand being nine-coordinated in a distorted muffin or spherical capped square antiprism-like geometry $\left(C_{S}\right.$ symmetry estimated through SHAPE 2.1 program, see Fig. S3 and Table S1 in ESI) [10]. The coordination sphere contains nine oxygen atoms: eight atoms arising from two $\mathrm{O}_{2} \mathrm{O}_{2}$ open compartments of the Schiff base ligands, and one atom from one methanol molecule. The $\mathrm{Tb}-\mathrm{O}$ distances vary between $2.334(8)$ and 2.577(8) Å. The copper ions, hosted in the inner $\mathrm{N}_{2} \mathrm{O}_{2}$ compartment, are pentacoordinated with a square-pyramidal geometry. The apical positions are occupied by cyanido nitrogen atoms, while the equatorial plane by the two oxygen and two nitrogen atoms from the Schiff base ligand [Cu1 $-\mathrm{N} 6 \mathrm{C}=2.196(11), \mathrm{Cu} 2-\mathrm{N} 1 \mathrm{C}=2.145(12), \mathrm{Cu} 1-01=1.949$ (8), $\mathrm{Cu} 1-\mathrm{O} 2=1.975(9), \mathrm{Cu} 1-\mathrm{N} 3=1.969(10), \mathrm{Cu} 1-\mathrm{N} 4=1.977$ (10), $\mathrm{Cu} 2-\mathrm{O} 3=1.965(8), \mathrm{Cu} 2-\mathrm{O} 4=1.996(8), \mathrm{Cu} 2-\mathrm{N} 1=1.994$ (10), and Cu2 - N2 = 1.974(10) $\AA$ ]. In this case, the values of the trigonality parameter [11] for the five-coordinate copper(II) ions are: $\tau_{\mathrm{Cu} 1}=6.42$ and, respectively, $\tau_{\mathrm{Cu} 2}=19.05 \%$. The values of the $\mathrm{CN}$ $\mathrm{Cu}$ angles are $150.98(11)$ and $151.20(10)^{\circ}$. The intrachain distances between the metal centers are as follows: Cu1 $\cdots \mathrm{Tb} 1=3.5366(15)$, $\mathrm{Tb} 1 \cdots \mathrm{Cu} 2=3.5103(15), \quad \mathrm{Cu} 1 \cdots \mathrm{O}{ }^{i} 1^{i}=5.243 ; \quad \mathrm{Cu} 2 \cdots \mathrm{O} 1 \mathrm{~s} 1=5.200 \AA$ $\left({ }^{i}=0.5+x, 0.5-y,-z\right)$. Selected bond distances and angles for compound $\mathbf{4}$ are gathered in Table S2.

\subsection{Magnetic properties}

The magnetic properties of the four complexes have been investigated between 300 and $1.8 \mathrm{~K}$. The present complexes are 


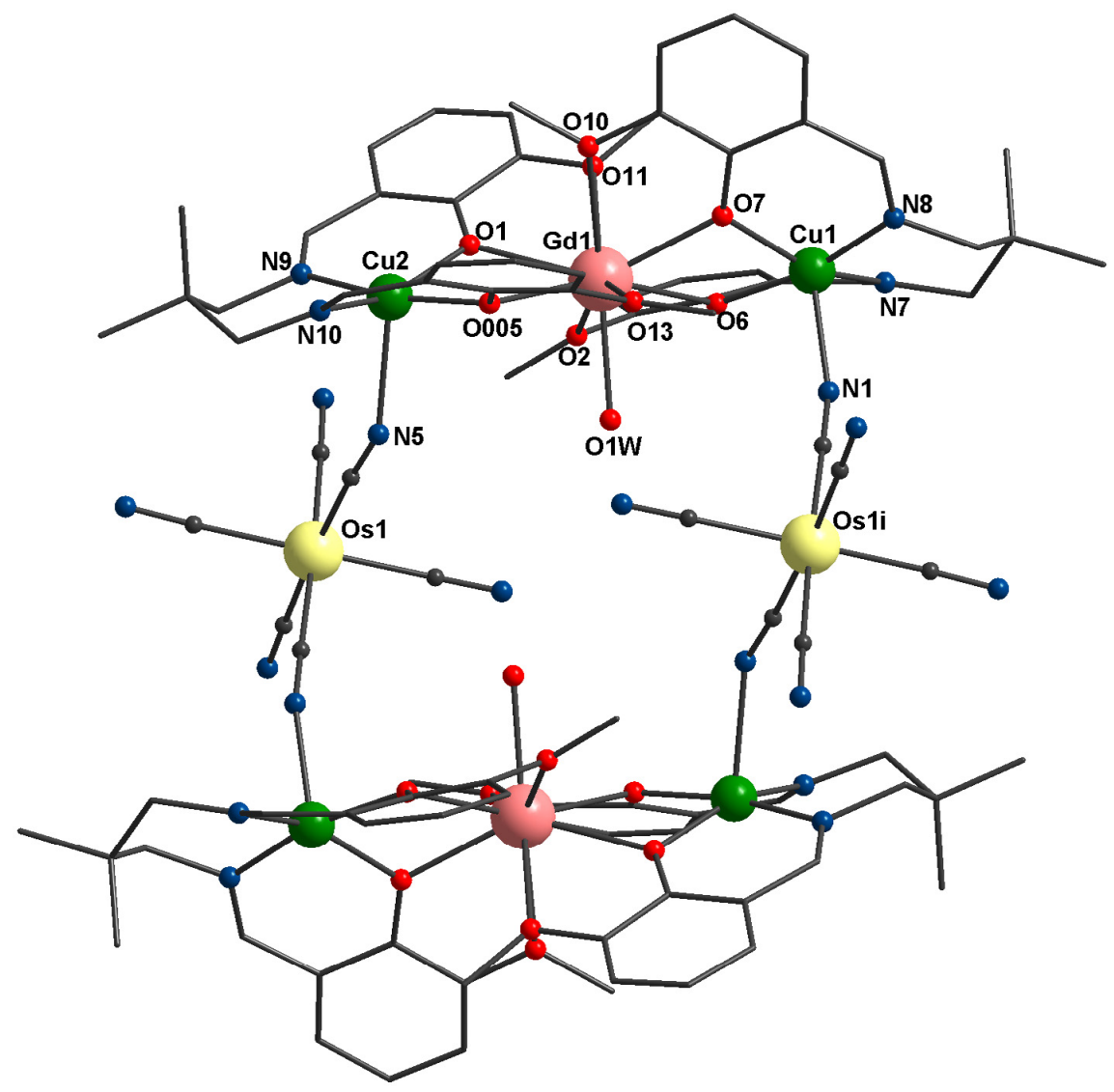

Fig. 1. Perspective view of the octanuclear complex 1 with the atom numbering scheme (color code: green - copper; pink - gadolium; yellow - osmium; red - oxygen; blue nitrogen) $\left({ }^{i}=2-x, 1-y, 2-z\right)$. The hydrogen atoms and crystallization solvent molecules have been removed for clarity.

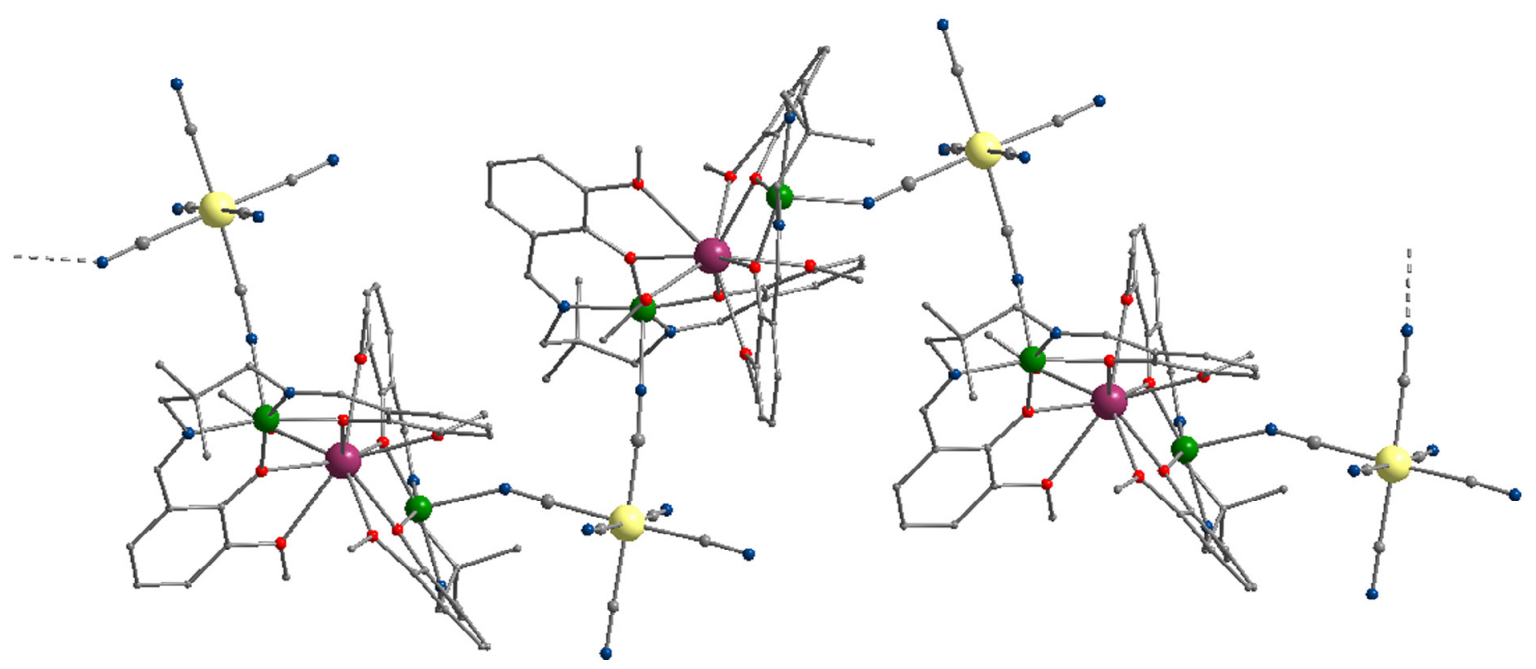

Fig. 2. View of the heterotrimetallic 1D coordination polymer in $\mathbf{4}$ (color code: green - copper; plum - terbium; yellow - osmium; red - oxygen; blue - nitrogen). The hydrogen atoms and crystallization solvent molecules have been removed for clarity.

composed of the same magnetic modules, $\left.\{\mathrm{Cu}(\text { valdmpn }))_{2} \mathrm{Ln}\right\}^{3+}$ and $\left[\mathrm{Os}(\mathrm{CN})_{6}\right]^{3-}$, forming octanuclear complexes for $\mathbf{1}$ and $\mathbf{2}$, and one-dimensional (1D) coordination network for $\mathbf{3}$ and $\mathbf{4}$ (vide supra), therefore, for a better comparison, the magnetic data reported herein have been normalized for only one $\{\mathrm{Cu}(-$ valdmpn $\left.)_{2} \operatorname{Ln}\right\}\left[\mathrm{Os}(\mathrm{CN})_{6}\right]$ formula unit. In Fig. 3, the temperature dependence of the $\chi T$ product for $\mathbf{1}$ and $\mathbf{3}$, the Gd analogues, is shown and highlights the similarity of the two magnetic behaviors. At high temperatures, the $\chi^{T}$ product for both compounds (10.1 versus $9.5 \mathrm{~cm}^{3} \mathrm{~K} \mathrm{~mol}^{-1}$ respectively) is consistent with the presence of one $S=7 / 2 \mathrm{Gd}(\mathrm{III})$ center (with $g=2$ ) [13], one $s=1 / 2$ Os (III) (with $g_{\text {eff }}=1.85$ ) $[7 \mathrm{c}, \mathrm{e}]$ and two $S=1 / 2 \mathrm{Cu}(\mathrm{II})$ (with $g=2.2$ ) 


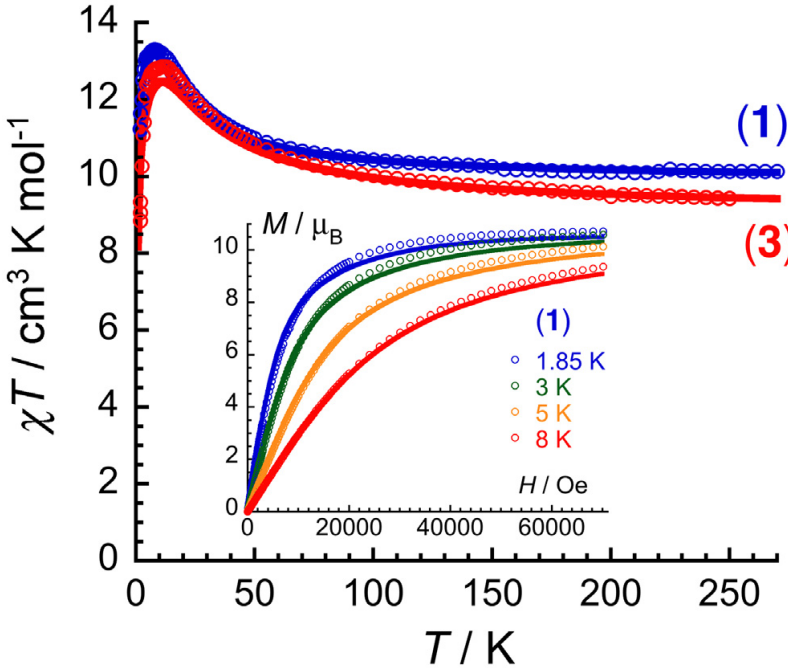

Fig. 3. Temperature dependence of the $\chi^{T}$ product at $0.1 \mathrm{~T}(\chi T$ is defined as magnetic susceptibility equal to $M / H$ per mole of $\left[\left\{(\mathrm{Cu}(\text { valdmpn }))_{2} \mathrm{Gd}\left(\mathrm{H}_{2} \mathrm{O}\right)\right\}\{\mathrm{Os}\right.$ $\left.\left.(\mathrm{CN})_{6}\right\}\right]$ unit) for $\mathbf{1}$ and 3. Inset: Field dependence of the magnetization below $8 \mathrm{~K}$ for 1 (scanning at $80-400$ Oe.min ${ }^{-1}$ for $H<1 \mathrm{~T}$ and $500-2500$ Oe.min ${ }^{-1}$ for $H>1 \mathrm{~T}$ ). Solid lines are simulations discussed in the text.

[13] metal ions for which a Curie constant of $9.1 \mathrm{~cm}^{3} \mathrm{~K} \mathrm{~mol}^{-1}$ is expected. By lowering the temperature, the $\chi T$ product increases, reaching a maximum of 13.3 and $12.9 \mathrm{~cm}^{3} \mathrm{~K} \mathrm{~mol}^{-1}$ at 8.1 and $10.6 \mathrm{~K}$ respectively. Below this temperature, a marked decrease of the $\chi T$ value is observed down to 11.2 and $8.8 \mathrm{~cm}^{3} \mathrm{~K} \mathrm{~mol}^{-1}$ at $1.85 \mathrm{~K}$. The magnetization vs. field curves (inset to Fig. 3 and Figs. S4-S5) below $8 \mathrm{~K}$ show a clear saturation at high dc fields close to the expected $10 \mu_{\mathrm{B}}$ (10.7 and $10.4 \mu_{\mathrm{B}}$ respectively) at $1.85 \mathrm{~K}$. Indeed, the magnetic properties of these two $\left\{\mathrm{Cu}_{2} \mathrm{GdOs}\right\}$ compounds can be understood qualitatively taking into account (i) that the $\mathrm{Cu}$..Gd interaction within bi- and trinuclear complexes with valXn ligands is almost always of ferromagnetic nature [4a,6a, $\mathrm{c}, 14]$, and (ii) that the apical $\mathrm{Cu}^{\mathrm{II}}-\mathrm{NC}-\mathrm{Os}^{\mathrm{III}}\left(\mathrm{d}^{5}\right.$, low spin) interaction is generally weak with a sign (ferro- or antiferromagnetic) being strongly influenced by the bridging $\mathrm{Cu}-\mathrm{NC}$ angle. Considering the spin topology from the crystal structure, the magnetic susceptibility data for $\mathbf{1}$ have been fitted using the following Heisenberg spin Hamiltonian that encompasses the whole octanuclear cyclic complex (Fig. 1):

$$
\begin{aligned}
\boldsymbol{H}= & -2 J_{\mathrm{Cu}-\mathrm{Gd}}\left(S_{\mathrm{Cu} 1} S_{\mathrm{Gd} 1}+S_{\mathrm{Gd} 1} S_{\mathrm{Cu} 2}+S_{\mathrm{Cu} 2 \mathrm{i}} S_{\mathrm{Gd} 1 \mathrm{i}}+S_{\mathrm{Gd} 1 \mathrm{i}} S_{\mathrm{Cu} 1 \mathrm{i}}\right) \\
& -2 J_{\mathrm{Cu}-\mathrm{Os}}\left(S_{\mathrm{Os} 1} S_{\mathrm{Cu} 2}+S_{\mathrm{Os} 1} S_{\mathrm{Cu} 1 \mathrm{i}}+S_{\mathrm{Os} 1 \mathrm{i}} S_{\mathrm{Cu} 1}+S_{\mathrm{Os} 11} S_{\mathrm{Cu} 2 \mathrm{i}}\right)
\end{aligned}
$$

In order to avoid over parameterization, the two $\mathrm{Cu} \ldots \mathrm{Gd}$ interactions as well as the two $\mathrm{Cu}$...Os interactions have been taken identical and thus the obtained parameters should be considered as average values. Moreover, the $g$ factor for the Os ${ }^{\mathrm{III}}$ center [7c, e] has been fixed to 1.85 in all the calculations done in the following. The simultaneous refinement of the $\chi T$ vs. $T$ and $M$ vs $H$ data with PHI [15] leads to the following set of reliable parameters: $g_{\mathrm{Gd}}=2.1(1), g_{\mathrm{Cu}}=2.3(1), J_{\mathrm{Cu}-\mathrm{Gd}} / k_{\mathrm{B}}=3.0(2) \mathrm{K}, J_{\mathrm{Cu}-\mathrm{Os}} / k_{\mathrm{B}}=-0.60$ (5) $\mathrm{K}$, and $z J^{\prime} / k_{\mathrm{B}}=-0.004(1) \mathrm{K}\left(J^{\prime}\right.$ being the average magnetic interactions between octanuclear complexes treated in the mean-field approximation [16] and $z$ the number of next neighbor complexes) and the theoretical curves shown in Figs. 3 and S4. This result indicates that the octanuclear complex 1 possesses an $S_{\mathrm{T}}=8$ ground state and that these high spin complexes are in weak antiferromagnetic interaction in the crystal packing. The modeling of the 1D compound $\mathbf{3}$ is in theory more complicated as it requires to consider the chain arrangement including an unprecedented spin

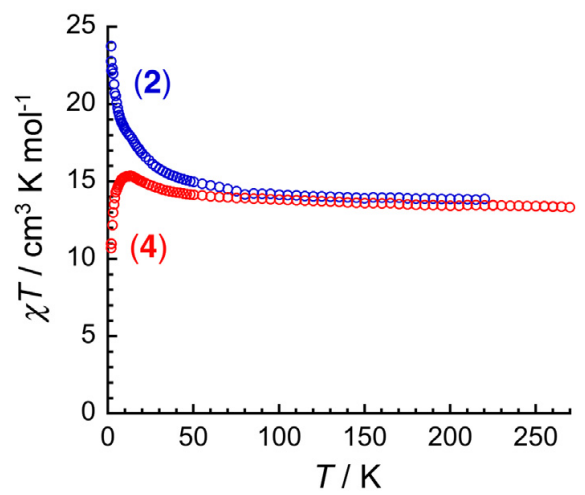

Fig. 4. Temperature dependence of the $\chi T$ product at $0.1 \mathrm{~T}(\chi T$ is defined as magnetic susceptibility equal to $M / H$ per mole of $\left[\left\{(\mathrm{Cu}(\text { valdmpn }))_{2} \mathrm{~Tb}\left(\mathrm{H}_{2} \mathrm{O}\right)\right\}\{\mathrm{Os}\right.$ $\left.\left.(\mathrm{CN})_{6}\right\}\right]$ unit) for $\mathbf{2}$ and $\mathbf{4}$.

$(1 / 2-7 / 2-1 / 2-1 / 2-\ldots)$ and interaction (that can be simplified to $J_{2^{-}}$ $J_{2}-J_{1}-J_{1}-\ldots$ using the same approximation than for $\left.\mathbf{1}\right)$ topologies. This kind of 1D systems are usually modeled considering spin loops of increasing number of repeating units. In that sense, the above Hamiltonian used to model $\mathbf{1}$ is indeed the first step and thus the first approximation to describe the magnetic properties of 3 considering a loop of two $1 / 2-7 / 2-1 / 2-1 / 2$ units. Remarkably this approach is sufficient to simultaneous fit [15] the $\chi T$ vs. $T$ and $M$ vs $H$ data with the following set of parameters: $g_{\mathrm{Gd}}=2.0$ (1), $g_{\mathrm{Cu}}=2.3(1), J_{\mathrm{Cu}-\mathrm{Gd}} / k_{\mathrm{B}}=5.4(1) \mathrm{K}, J_{\mathrm{Cu}-\mathrm{Os}} / k_{\mathrm{B}}=-0.63(5) \mathrm{K}$, and $z J^{\prime} \mid$ $k_{\mathrm{B}}=-0.007(1) \mathrm{K}$. As expected from Fig. 3 and the similarity of the magnetic properties, the obtained couplings are similar to those obtained for 1 leading at low temperatures to $S_{\mathrm{T}}=4$ \{CuGdCuOs $\}$ units in effective ferromagnetic interaction along the chains, which are themselves in weak antiferromagnetic interactions in the crystal packing.

The magnetic properties of the compounds 2 and $\mathbf{4}$, the Tb analogues, are shown in Fig. 4 and S6-S7 as $\chi T$ vs. $T$ and $M$ vs $H$ data respectively. The $\chi^{T}$ product at high temperatures for both compounds (13.8 versus $13.3 \mathrm{~cm}^{3} \mathrm{~K} \mathrm{~mol}^{-1}$ respectively) is in good agreement with the presence of one $\mathrm{Tb}(\mathrm{III})$ center $(S=3, L=3$, ${ }^{7} F_{6}, \chi T=11.8125 \mathrm{~cm}^{3} \mathrm{~K} \mathrm{~mol}^{-1}$ with $\left.g=3 / 2\right)$ [13], one $s=1 / 2$ Os (III) (with $g_{\text {eff }}=1.85$ ) $[7 c, e]$ and two $S=1 / 2 \mathrm{Cu}$ (II) (with $g=2.2$ ) [13] metal ions for which a $\chi T$ product of $12.6 \mathrm{~cm}^{3} \mathrm{~K} \mathrm{~mol}^{-1}$ is expected. By lowering the temperature, the $\chi T$ product increases as a sign of the dominating $\mathrm{Cu} \ldots \mathrm{Tb}$ ferromagnetic interactions [17] and reaches a maximum of 23.8 and $15.4 \mathrm{~cm}^{3} \mathrm{~K} \mathrm{~mol}^{-1}$ at 1.85 and $13 \mathrm{~K}$ respectively. While no sign of additional antiferromagnetic interactions is observed for $\mathbf{2}$, a marked decrease of the $\chi T$ value is observed for 4 below $13 \mathrm{~K}$, to $10.7 \mathrm{~cm}^{3} \mathrm{~K} \mathrm{~mol}^{-1}$ at $1.85 \mathrm{~K}$. As the magnetic properties of the $\{\mathrm{CuTbCu}\}$ module are expected to be relatively robust between 2 and 4 , these results suggest that the $\mathrm{Cu}$...Os magnetic interaction or the $z J^{\prime}$ parameter are strongly modified between a pair and a chain of $\{\mathrm{CuTbCuOs}\}$ units. While the lack of magnetization saturation at high field is observed for both $\{\mathrm{CuTbCuOs}\}$-based complexes as expected in presence of anisotropic Tb centers (Figs. S6-S7), the presence of additional antiferromagnetic interactions in $\mathbf{4}$ is also seen on the magnetization vs. field curves below $8 \mathrm{~K}$. Accordingly, the magnetization at $7 \mathrm{~T}$ and $1.85 \mathrm{~K}$ is much lower for 4 than for 2 (7.9 versus $9.4 \mu_{\mathrm{B}}$ respectively).

\section{Conclusions}

The four compounds described herein enlarge the still small family of heterotrimetallic complexes with new members, which 
represent the first $3 \mathrm{~d}-4 \mathrm{f}-5 \mathrm{~d}$ systems constructed using $\left[\mathrm{Os}(\mathrm{CN})_{6}\right]^{3-}$ as a metalloligand module. In addition, it is worth emphasizing that compounds $\mathbf{1}$ and $\mathbf{2}$ are rare examples of high-spin octanuclear heterotrimetallic metallocycles but that unfortunately none of these molecular species nor their one-dimensional analogues display slow dynamics of their magnetization in our experimental windows (as probed by ac susceptibility measurements above $1.8 \mathrm{~K}$, between 0 and $1 \mathrm{~T} \mathrm{dc}$ field, and with ac-fields with 0.1 to $10000 \mathrm{~Hz}$ ac frequency). Further work on this topic, based on other $3 \mathrm{~d}-4 \mathrm{f}$ modules, is in progress in our laboratories.

\section{Acknowledgements}

We are grateful to the UEFISCDI (project PN-III-P4-ID-PCE2016-0321), the CNRS, the University of Bordeaux, the Conseil Régional de Nouvelle Aquitaine, the MOLSPIN COST action CA15128 and the GdR MCM-2: Magnétisme et Commutation Moléculaires for financial support.

\section{References}

[1] See, for example: (a) O. Kahn Adv. Inorg. Chem. 43 (1995) 179-259;

(b) K.S. Pedersen, J. Bendix, R. Clérac, Chem. Commun. 50 (2014) 4385-4512;

(c) S. Goswani, A.K. Mondal, S. Konar, Inorg. Chem. Front. 2 (2015) 687-712;

(d) H. Miyasaka, M. Julve, M. Yamashita, R. Clérac, Inorg. Chem. 48 (2009) 3420-3437;

(e) H.-L. Sun, Z.-M. Wang, S. Gao, Coord. Chem. Rev. 254 (2010) 1081-1100.

[2] S. Akine, T. Matsumoto, T. Nabeshima, Angew. Chem., Int. Ed. 55 (2015) 960 964.

[3] C.N. Verani, E. Rentschler, T. Weyermüller, E. Bill, P. Chaudhuri, J. Chem. Soc., Dalton Trans. (2000) 4263-4271.

[4] (a) R. Gheorghe, M. Andruh, J.-P. Costes, B. Donnadieu, Chem. Commun. (2003) 2778-2779;

(b) T. Shiga, H. Okawa, S. Kitagawa, M. Ohba, J. Am. Chem. Soc. 128 (2006) 16426-16427;

(c) S. Dhers, H.L.C. Feltham, R. Clérac, Inorg. Chem. 23 (2013) 13685-13691.

[5] See, for example: (a) D.S. Nesterov, V.N. Kokozay, B.W. Skelton Eur. J. Inorg. Chem. (2009) 5469-5473; (b) R. Podgajni, S. Chorazy, J. Nitek, M. Rams, A.M. Majcher, B. Marszalek, J. Zukrowski, C. Kapusta, B. Sieklucka, Angew. Chem., Int. Ed. 52 (2013) 896-900.

[6] (a) D. Visinescu, A.M. Madalan, M. Andruh, C. Duhayon, J.-P. Sutter, L. Ungur, W. Van den Heuvel, L. Chibotaru, Chem.-Eur. J. 15 (2009) (1814) 11808-11811; (b) M.-G. Alexandru, D. Visinescu, A.M. Madalan, F. Lloret, M. Julve, M. Andruh, Inorg. Chem. 51 (2012) 4906-4908;

(c) D. Visinescu, M.-G. Alexandru, A.M. Madalan, C. Pichon, C. Duhayon, J.-P. Sutter, M. Andruh, Dalton Trans. 44 (2015) 16713-16727;

(d) M.-G. Alexandru, D. Visinescu, M. Andruh, N. Marino, D. Armentano, J. Cano, F. Lloret, M. Julve, Chem.-Eur. J. 21 (2015) 5429-5446;

(e) D. Visinescu, I.-R. Jeon, A.M. Madalan, M.-G. Alexandru, B. Jurca, C. Mathonière, R. Clérac, M. Andruh, Dalton Trans. 41 (2012) 13578-13581.

[7] See, for example: (a) M.G. Hilfiger, M. Shatruk, A. Prosvirin, K.R. Dunbar Chem. Commun. (2008) 5752-8754:

(b) M.G. Hilfiger, M. Chen, T.V. Brinzari, T.M. Nocera, M. Shatruk, D.T. Petatis, J. L. Musfeldt, C. Achim, K.R. Dunbar, Angew. Chem., Int. Ed. 49 (2010) 14101413;

(c) K.S. Pedersen, M. Schau-Magnussen, J. Bendix, H. Weihe, A.V. Palii, S.L. Klokishner, S. Ostrosvsky, O.S. Reu, H. Mutka, P.L.W. Tregenna-Piggott, Chem. Eur. J. 16 (2010) 13458-13464;

(d) K.S. Pedersen, J. Dreiser, J. Nehrkorn, M. Gysler, M. Schau-Magnussen, A. Schnegg, K. Holldack, R. Bittl, S. Piligkos, H. Weihe, P. Tregenna-Piggott, O. Waldmann, J. Bendix, Chem. Commun. 47 (2011) 6918-6920;

(e) J. Dreiser, K.S. Pedersen, A. Schnegg, K. Holldack, J. Nehrkorn, M. Sigrist, P. Tregenna-Piggott, H. Mutka, H. Weihe, V.S. Mironov, J. Bendix, O. Waldmann, Chem.-Eur. J. 19 (2013) 3693-3701;

(f) V. Hoeke, A. Stammler, H. Bögge, J. Schnack, T. Glaser, Inorg. Chem. 53 (2014) 257-268;

(g) E. Peresypkina, A.M. Majcher, M. Rams, K.E. Vostrikova, Chem. Commun. 50 (2014) 7150-7153.

[8] (a) R. Gheorghe, P. Cucos, M. Andruh, J.-P. Costes, B. Donnadieu, S. Shova, Chem. Eur. J. 12 (2006) 187-203;

(b) R. Gheorghe, M. Andruh, A. Müller, M. Schmidtmann, Inorg. Chem. 41 (2002) 5314-5316.

[9] P. Albores, L.P. Slep, L.M. Baraldo, R. Baggio, M.T. Garland, E. Rentschler, Inorg. Chem. 45 (2006) 2361-2363.

[10] (a) M. Llunell, D. Casanova, J. Cirera, J.M. Bofill, P. Alemany, S. Alvarez, M. Pinsky, D. Avnir, SHAPE: Continuous shape measures of polygonal and polyhedral molecular fragments, 1.1b; University of Barcelona: Barcelona (2005): (b) D Casanova, M. Llunell, P. Alemany, S. Alvarez Chem. Eur. J. 11 (2006); $1479-1494$.

[11] A.W. Addison, T.N. Rao, J. Reedijk, J.V. Rijn, G.C. Verschor, J. Chem. Soc., Dalton Trans. (1984) 1349-1356.

[12] K.-Q. Hu, X. Jiang, S.-Q. Wu, C.-M. Liu, A.-L. Cui, H.-Z. Kou, Inorg. Chem. 54 (2015) 1206-1208.

[13] R.L. Carlin, Magnetochemistry, Springer-Verlag, Berlin, 1986.

[14] (a) J.-P. Costes, F. Dahan, A. Dupuis, J.-P. Laurent, Inorg. Chem. 35 (1996) 24002402;

(b) H. Zhou, C. Chen, J. Lu, Y. Liu, X. Shen, Inorg. Chim. Acta 453 (2016) 482487;

(c) D. Visinescu, M.-G. Alexandru, A.M. Madalan, I.-R. Jeon, C. Mathonière, R. Clérac, M. Andruh, Dalton Trans. 45 (2016) 7642-7649;

(d) J.-P. Costes, B. Donnadieu, R. Gheorghe, G. Novitchi, J.-P. Tuchagues, L. Vendier, Eur. J. Inorg. Chem. (2008) 5235-5244.

[15] (a) N. F. Chilton, R. P. Anderson, L. D. Turner, A. Soncini, K. S. Murray, S. J. Comput. Chem. 34 (2013) 1164-1175; (b) N. F. Chilton, PHI User Manual v2.1 (2015).

[16] (a) C.J. O'Connor, Prog. Inorg. Chem. 29 (1982) 203-283;

(b) B.E. Myers, L. Berger, S. Fridberg, J. Appl. Phys. 40 (1969) 1149-1151.

[17] See, for example: (a) J. Long, L.-M. Chamoreau, V. Marvaud Dalton Trans. 39 (2010) 2161-2452;

(b) N. Bridonneau, L.-M. Chamoreau, P.P. Laine, W. Werndorfer, V. Marvaud, Chem. Commun. 49 (2013) 9476-9478;

(c) N. Bridonneau, G. Gontard, V. Marvaud, Dalton Trans. 44 (2015) 5170-5178. 